\title{
Factors Affecting the Enforcement of Money Laundering in Indonesian Criminal Justice Systems
}

\author{
Muhammad Djamir \\ Doctoral Program in Law Science \\ Sultan Agung Islamic University, UNISSULA \\ Semarang, Indonesia
}

\author{
Sri Endah Wahyuningsih \\ Faculty of Law \\ Sultan Agung Islamic University, UNISSULA \\ Semarang, Indonesia
}

\begin{abstract}
Law enforcement against the perpetrators of money laundering crimes in Indonesia is still not optimal because it is related to other criminal acts which constitute predicate crimes. This study aims to find and analyze the process of law enforcement against the perpetrators of money laundering crimes in the criminal justice system in Indonesia and the factors that influence it. The method of approach in this research is sociological juridical, with primary and secondary data sources. Primary data were obtained by conducting interviews with four judges in Sumber District and Cirebon district courts whereas secondary data is obtained by conducting a literature study on the legislation, research results, journals, books, legal dictionaries. The data obtained were then analyzed using qualitative descriptive methods. The results showed that the process of law enforcement for money laundering in Indonesia is based on Article 69 of Law Number 8 of 2010 concerning Prevention and Eradication of Money Laundering Criminal Acts, stipulating that investigations, prosecutions and examinations at a court hearing cannot be proven. Predicate crime (predicate crime), as for the factors that influence the process of law enforcement against the perpetrators of the factors covering the legislation, lack of cooperation between law enforcement officials and the legal culture.
\end{abstract}

Keywords:- Money Laundering; Criminal Acts; Law Enforcement; Criminal Justice System.

\section{INTRODUCTION}

Money laundering is now a crime that has an extensive scope, due to the crime of money laundering, which is the result of another crime in which the perpetrator disguises the assets obtained from the crime to be as if obtained legally. Money laundering has a severe impact, especially on the stability of the country's financial system and economy, is a multidimensional and transnational crime that often involves a large amount of money. The crime of money laundering is organized crime so that prevention and prevention is the responsibility of the state. In its development, the crime of money laundering is increasingly complex, crossing the boundaries of jurisdiction, and using a more varied mode, utilizing institutions outside the financial system, even has penetrated various sectors. To anticipate this, the Financial Action Task Force (FATF) on Money Laundering has issued international standards that become a measure for each country in the prevention and eradication of money laundering, known as Revised 40 Recommendations and 9 Special Recommendations (Revised $40+9$ ) FATF [1].

Also, in the prevention and eradication of the crime of money laundering, regional and international cooperation needs to be carried out through bilateral or multilateral forums so that the intensity of criminal acts that result in or involve a large number of assets can be minimized. This cooperation is not only related to the understanding of regulations or general principles that apply, but also related to cooperation to provide access to legal assistance relating to the enforcement of money laundering. Handling of money laundering in Indonesia is based on Law Number 8 of 2010 concerning Prevention and Eradication of Money Laundering Crimes. However, from previous research, it is known that these laws and regulations still provide spaces for different interpretations, legal loopholes, imprecise sanctions, not yet utilized shifts in the burden of proof, limited access to information, the narrow scope of the reporter and the type of report, and lack of clarity the duties and authorities of the executors especially about extraordinary crimes as the initial crime. So the goal to prevent and break the chain of a criminal offense has not yet been realized [2].

The process of enforcing criminal law on money laundering in Indonesia has challenges including the offender is only sentenced to prison and fines, while the proceeds of crime remain in the power of the offender; rarely do perpetrators be able to return the proceeds of crimes of the perpetrators of money laundering crimes that were initially crimes of narcotics and corruption, have massive wealth and the possibility of committing crimes from prison such as narcotics transactions. The portrait provides a sign that law enforcement of money laundering is not optimal. Therefore, the purpose of this study is to analyze the process of law enforcement of money laundering crimes and the factors that influence the process of law enforcement against money laundering criminals in Indonesia [3]. 


\section{RESEARCH METHOD}

The method used in this research is the law and case approach, namely by digging data from cases handled by judges who have tried money laundering cases. The data in this study are primary data and secondary data. Primary data was obtained by conducting interviews with judges who had handled cases of money laundering in the Cirebon District Court and Sumber District Court who had jurisdiction over handling cases of money laundering by the focus of the study in this study. The secondary data was obtained by conducting a literature study consisting of primary legal materials in the form of legislation, secondary legal materials in the form of books, journal articles and tertiary legal materials in the form of dictionaries and encyclopedias. The data obtained were then analyzed using the qualitative descriptive method.

\section{RESULT AND DISCUSSION}

\section{A. Enforcement of Criminal Laundering of Money Laundering in Indonesia}

In Money Laundering is a process to hide or disguise the proceeds of crime so that the money appears to come from the results of legal activities and is reinvested into a legal, economic system so that perpetrators can enjoy the money without any fear of being confiscated by law enforcement officials [4].

Money laundering is closely related to Suspicious Financial Transactions. Suspicious Financial Transactions are:

$>$ Financial transactions that deviate from the profile, characteristics, or habits of the transaction patterns of the service users concerned;

$>$ financial transactions by service users that are reasonably suspected of being carried out to avoid reporting the relevant transactions which must be carried out by the reporting party by the provisions of this law;

$>$ Financial transactions conducted or cancelled by using Assets that are suspected to originate from the proceeds of crime; or

$>$ Financial transactions requested by PTPK to be reported by the reporting party because it involves assets suspected to originate from criminal proceeds.

Law Number 8 of 2010 concerning Prevention and Eradication of Money Laundering (TPPU) regulates the investigation, prosecution and examination explicitly at a court hearing. This case confirmed in Article 68 which states that the investigation, prosecution, and examination in a court of law and the implementation of decisions that have obtained permanent legal force against criminal offenses as referred to in this law are carried out by the provisions in this law. In Article 69 of Law Number 8 of 2010 concerning Prevention and Eradication of Money Laundering, it is not required to prove that investigations, prosecutions, and examinations at a court of law for Money Laundering, Predicate Crimes must not be proven in advance first Follow-up crime (follow-up crime) is a continuation of the original crime (predicate crime), as an effort to hide or eliminate traces, in such a way that it cannot be known that the assets originated from criminal acts. Therefore, predicate crime (predicate crime) is a criminal offense that generates money/assets which are then carried out the washing process. So it is impossible for a Money Laundering Criminal Act without the original criminal offense [5].

Based on the Constitutional Court Decision No. $35 /$ PUU-XV / 2017, the Constitutional Court affirmed that the Criminal Act of Money Laundering is a criminal act that stands alone, but is preceded and may be followed by other criminal acts. Money Laundering is part of a series of interrelated crimes. This confirms that the eradication of TPPU is based on the principle of following the money, not follow the person, because the criminal acts are intertwined with transferring assets from one hand to the other. Therefore, to conduct investigations, prosecutions and examinations in TPPU cases, it must be preceded by an original criminal act, but the original criminal act is not required to be proven first. So that the TPPU does not need to wait long until the original criminal case is decided or has obtained permanent legal force [6].

The investigator, public prosecutor, or judge has the authority to order the Reporting Party to postpone the Transaction on Assets known or reasonably suspected to be the result of a criminal offense. Transaction Postponement is conducted no later than 5 (five) working days. Reporting Parties must carry out a postponement of the transaction shortly after the order/request for the postponement of the transaction is received from the investigator, public prosecutor, or judge. Reporting Parties are required to submit minutes of executing transaction delays to investigators, public prosecutors, or judges who request a transaction delay no later than 1 (one) working day from the date of carrying out the transaction delay. The investigator, public prosecutor, or judge has the authority to order the reporting party to block assets that are known or reasonably suspected to be the result of a criminal offense of:

$>$ Any person who has been reported by PPATK to the investigator;

$>$ suspect; or

$>$ defendant.

Reporting parties must carry out the blocking shortly after the blocking order was received from the investigator, public prosecutor, or judge. In the event of a blocking being carried out, the assets that are blocked must remain with the Reporting Party concerned [7].

Valid evidence is proving money laundering is:

$>$ evidence as referred to in the Criminal Procedure Code; and

$>$ other evidence in the form of information that is spoken, sent, received, or stored electronically with optical devices or tools similar to optics and documents.

Investigation of a Money Laundering act is carried out by an investigator of an original crime following the provisions of the procedural law and the provisions of the 
legislation unless otherwise stipulated. The original criminal investigator is an official from an institution authorized by law to conduct an investigation, namely the Indonesian National Police, the Attorney General's Office, Corruption Eradication Commission (KPK), the National Narcotics Agency (BNN), and the Directorate General of Tax and the Directorate General of Customs and Excise Ministry of Finance of the Republic of Indonesia. However, based on the Constitutional Court Decision No.74 / PUU-XVI / 2018, it is decided that the explanation of Article 74 of Law Number 8 of 2010 concerning Prevention and Eradication of Money Laundering Acts is contrary to the 1945 Constitution of the Republic of Indonesia and does not have binding legal force, as long as it is not interpreted " what is meant by "original criminal investigator" is an official or institution that by law is given the authority to conduct an investigation " [8].

The original criminal investigator can conduct a Money Laundering crime if he finds sufficient initial evidence of the occurrence of a Money Laundering crime when investigating the original criminal offense according to his authority. If the investigator has found sufficient preliminary evidence of the crime of money laundering and original crime, the investigator can combine the investigation of the original crime with the investigation of the crime of money laundering and notify the Financial Transaction Reports and Analysis Center (PPATK).

In Article 2 of Law Number 8 of 2010 concerning Prevention and Eradication of Money Laundering, predicate crime can be in the form of corruption, bribery, narcotics, psychotropic, labour smuggling, migrant smuggling, criminal acts in banking, criminal offenses in the capital market, criminal offenses in the field of insurance, customs offenses, excise, trafficking in persons, trafficking in illegal weapons, terrorism, kidnapping, theft, embezzlement, fraud, counterfeiting of money, gambling, prostitution, criminal acts in taxation, criminal offenses in the field of forestry, criminal offenses in the environmental field, criminal offenses in the field of maritime affairs and fisheries criminal offenses, or other criminal offenses threatened with imprisonment of 4 (four) years or more (based on MK Decree No. No.74 / PUU -XVI / 2018 is replaced with a criminal act that is threatened with a prison sentence of 1 year or more). Committed in the territory of the Unitary Republic of Indonesia or outside the territory of the Unitary State of the Republic of Indonesia and the crime is also a crime according to Indonesian law. Assets that are known or reasonably suspected to be used and used directly or indirectly for terrorist activities, terrorist organizations, or individual terrorists are equated as a result of criminal acts [9].

After completing the investigation process, the case is delegated to the public prosecutor, and the public prosecutor is obliged to submit the Money Laundering case file to the district court no later than 30 (thirty) working days from the date of receipt of the case file that has been declared complete. If the public prosecutor has submitted the case file to the district court, the head of the district court must appoint the panel of judges no later than 3 (three) working days after receipt of the case file. In Article 77 of Law Number 8 the Year 2010 concerning Prevention and Eradication of the Criminal Act of Money Laundering (TPPU) examination at the Court Hearing, the defendant must prove that his assets are not the result of a criminal offense or often referred to as reverse proof by submitting sufficient evidence [10].

Defendants who have been legally summoned and should not be present at court without a valid reason, the case can be examined and decided without the presence of the defendant. If the defendant is present at the next hearing before the verdict is rendered, the defendant must be examined, and all witness statements and letters read in the previous trial are considered as pronounced in the current trial. Decisions handed down without the presence of the defendant are announced by the public prosecutor on the court notice board, local government office, or notified to their attorneys. If the defendant dies before the verdict is handed down and there is sufficient evidence that the person has committed the crime of money laundering, the judge in the demands of the public prosecutor can decide the confiscation of confiscated assets [11].

Determination of the seizure can not be applied for legal remedies. Any interested person / legal entity can file an objection to the court which has dropped the decision within 30 (thirty) days from the date of the announcement. If related to the regulation of money laundering (TPPU), in Article 67 of Law Number 8 the Year 2010, this is in line with the context of TPPU law enforcement. Even though this is different, the spirit of eradicating money laundering related to assets obtained from the original crime is regulated, in the case that no person and third party submits an objection within 20 (twenty) days from the temporary termination of the Transaction, PPATK submits the handling of Assets known or reasonably suspected to be the proceeds of the crime to the investigator for investigation. If the alleged perpetrator is not found within 30 (thirty) days, the investigator can apply to the district court to decide the Assets. These assets are the assets of the state or returned to those entitled to them. In this case, the court must decide within a maximum period of 7 (seven) days [12].

\section{B. Factors Affecting Law Enforcement of Money Laundering Actions in Indonesia}

Factors affecting the legal substance include, in the period 2010-2013, there is still a legal vacuum regarding matters of procedure for settling applications for handling assets in a criminal offense or another crime. Therefore, to fill the legal vacuum, the Supreme Court has issued Supreme Court Regulation Number 1 of 2013 concerning Procedures for Settling Requests for Handling Assets in Washing Crimes or Other Crimes. The legal vacuum is the legal vacuum of procedural law for the implementation of Article 67 of Law Number 8 the Year 2010 concerning Prevention and Eradication of Money Laundering Crimes. The article stipulates that if no person and third party submit an objection within 20 (twenty) days from the date of the temporary cessation of the transaction, the PPATK shall 
surrender the handling of assets known or reasonably suspected to be the proceeds of the crime to the investigator for carried out an investigation [13].

If the alleged offender is not found within 30 (thirty) days, the investigator may apply to the district court to decide the assets as state assets or return them to the rightful ones. The court must decide within a maximum of 7 (seven) days. The Supreme Court Regulations regulate the procedures for settling applications for handling assets in the crime of money laundering or other criminal acts. The TPPU law enforcement process is inseparable from the criminal justice system in force in Indonesia. The current criminal justice system in Indonesia has a great challenge to prevent and eradicate TPPU related to narcotics crime. This is because the current portrait shows that the offender is only sentenced to prison and fines, the proceeds of crime remain the power of the offender, in some instances if only using law enforcement facilities related to narcotics, it is not possible to find and return proceeds. Crime, the perpetrators / convicted of narcotics crime have a vast fortune from the results of a significant crime but can conduct narcotics transactions from behind bars/jail and even though they have used the means of money laundering still found difficulties in disclosing and combating Narcotics crime [14].

Another factor affecting the law enforcement of money laundering is the broad scope of the original crime in money laundering, showing two parameters. First, with so many original criminal acts in the TPPU, law enforcement needs to be optimized. Second, law enforcement that has been implemented has not been able to provide a deterrent effect for perpetrators of the original crime. One of them is related to narcotics crime. Since 20015, there have been more than
137 decisions of TPPU cases and based on the alleged criminal offenses, in which corruption is the highest decision with 40 decisions or $29.2 \%$ compared to those with other alleged criminal acts and Narcotics is ranked second as the predicate crime. This is based on data from the Financial Transaction Reports and Analysis Center (PPATK), which is an independent institution formed in order to prevent and eradicate money laundering [15].

Another factor influencing the law enforcement process Money laundering is the increasingly complex problem of money laundering, because it crosses jurisdictional boundaries, and uses an increasingly sophisticated and varied modus operandi by utilizing advances in science and technology and utilizing institutions outside the financial system, even has penetrated various other sectors. Laws that do not run dynamically when juxtaposed with the development of human civilization will increasingly be seen to have flaws and even emptiness. Therefore, with the development of human civilization, especially in Indonesia, the development of TPPU law enforcement related to money laundering should be harmonized with the needs and changes that have preceded it [16].

Another factor that influences is the legal culture which includes the community's low legal awareness to report money laundering. This is evident from the detailed comparison of the number of TPPU case decisions from 2005 to 2015 based on the alleged original crime as follows:

Comparative Data Amount of Decisions on Tppu Cases Period of January 2005 to November 2015 Based on the Origin of Criminal Action

\begin{tabular}{|c|c|c|c|}
\hline No & Criminal Origin & $\begin{array}{c}\text { Total } \\
\text { Decisions }\end{array}$ & Percentage \\
\hline 1 & Corruption & 40 & $29.2 \%$ \\
\hline 2 & Narcotics & 36 & $26.3 \%$ \\
\hline 3 & Fraud & 16 & $11.7 \%$ \\
\hline 4 & Embezzlement & 15 & $10.9 \%$ \\
\hline 5 & Banking & 11 & $8.0 \%$ \\
\hline 6 & Letter forgery & 6 & $4.4 \%$ \\
\hline 7 & Psychotropic drugs & 2 & $1.5 \%$ \\
\hline 8 & Gambling & 2 & $1.5 \%$ \\
\hline 9 & Theft & 1 & $0.7 \%$ \\
\hline 10 & Violation of Cash Carry & 1 & $0.7 \%$ \\
\hline 11 & Forestry & 1 & $0.7 \%$ \\
\hline 12 & Bribery & 1 & $0.7 \%$ \\
\hline 13 & Other Crimes & 5 & $3.6 \%$ \\
\hline
\end{tabular}

Table 1

These data indicate that the predicate crime of money laundering crimes originating from corruption is the highest, then narcotics crime is in the second position after corruption. This can reflect the legal culture in Indonesia, especially the awareness of the rule of law for a citizen is still far from what is expected. In the context of factors affecting law enforcement, the legal culture provides 2 (two) parameters. First, the legal culture of law enforcement officers in carrying out their duties and functions that are not yet optimal, facilities and infrastructure as well as limited human resources both investigators, public prosecutors and judges, as well as the lack of public legal awareness to understand the laws in force in Indonesia [1]. 


\section{CONCLUSIONS}

The process of law enforcement of money laundering in Indonesia is based on Article 69 of Law Number 8 the Year 2010 concerning Prevention and Eradication of Money Laundering Criminal Acts, determining that investigations, prosecutions and examinations in Money Court Crimes can be carried out to be carried out., Predicate crime (predicate crime) is not required to be proven first.

$>$ Factors affecting law enforcement against perpetrators of money laundering crimes in Indonesia include legal substance factors, gaps in legislation, factors of legal structure and legal structure with the more advanced development of science and technology, the more sophisticated the modus operandi of acts money laundering crimes, besides that there are also limited human resources both public prosecutors and judges, as well as low legal awareness of the community.

\section{REFERENCES}

[1]. C. Gikonyo, "International Journal of Law, Crime and Justice Rationalising the use of the anti-money laundering regime in tackling Somalia's piracy for ransoms," Int. J. Law Crime Justice., vol. 52, no. July 2017, pp. 155-164, 2018.

[2]. S. E. Wahyuningsih, "PENANGGULANGAN MONEY LAUNDERING DALAM RANGKA," vol. II, no. 1, pp. 46-56, 2015.

[3]. S. E. Wahyuningsih, R. Samodra, and D. Wahyono, "THE IMPLEMENTATION OF RESTORATIVE JUSTICE IN THE TRAFFIC CRIME INVESTIGATION PROCEDURES IN," vol. 97, no. 24, pp. 97-109.

[4]. S. E. Wahyuningsih, A. Indah, and M. Iksan, "The implementation of restorative justice to children as perpetrator in criminal investigation in Indonesia," Test Eng. Manag., vol. 83, no. 2746, pp. 2746-2752, 2020.

[5]. F. Sivertsson, "Adulthood-limited offending: How much is there to explain?" J. Crim. Justice, vol. 55, no. December 2017, pp. 58-70, 2018.

[6]. S. Isra, Yuliandri, F. Amsari, and H. Tegnan, "Obstruction of justice in the effort to eradicate corruption in Indonesia," Int. J. Law, Crime Justice, vol. 51, pp. 72-83, 2017.

[7]. H. Kim, M. Button, and J. Lee, "International Journal of Law, Crime and Justice Public perceptions of private security in shopping malls: A comparison of the United Kingdom and South Korea," Int. J. Law Crime Justice., vol. 53, no. April 2017, pp. 89-100, 2018.

[8]. P. Reuter and E. M. Truman, "Money Laundering: Methods and Markets," Chas. Dirty Money Fight against money Laund., pp. 25-43, 2003.

[9]. A. Maksum and Surwandono, "Suffer to survive: The Indonesian illegal worker's experiences in Malaysia and Japan,” J. Soc. Res. Policy, vol. 8, no. 1, pp. 101123, 2017.
[10]. J. Emirzon, "Bentuk Praktis dan Modus Tidak Pidana Pencucian Uang," 2017.

[11]. S. E. Wahyuningsih, S. Atmoko, and M. Iksan, "The implementation of punishment theories in the verdict of narcotics case by judge in Indonesia," Test Eng. Manag., vol. 83, no. 2797, pp. 2797-2806, 2020.

[12]. M. J. Anderson and T. A. Anderson, "Anti-Money Laundering: History and Current Developments," J. Int. Bank. Law Regul., vol. 30, no. 10, pp. 521-531, 2015.

[13]. M. Levi and P. Reuter, "Money Laundering," Oxford Handb. Crime Public Policy, no. 2004, 2012.

[14]. H. Sarigul, "Money Laundering and Abuse of the Financial System," Int. J. Bus. Manag. Stud., vol. 2, no. 1, pp. 287-301, 2013.

[15]. M. Y. bin Z. Kepli and M. A. Nasir, "Money Laundering: Analysis on the Placement Methods," Int. J. Business, Econ. Law, vol. 11, no. 5, p. 9, 2016.

[16]. S. E. Wahyuningsih, I. D. P. G. A. Danujaya, and M. Iksan, "Policy of criminal sanctions against corporations using illegal foreign workers in Indonesia," Int. J. Innov. Creat. Chang., vol. 12, no. 10, pp. 166-182, 2020. 